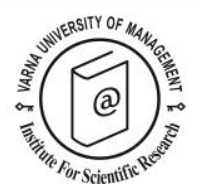

\title{
Examining the effects of personal factors and travel characteristics on tourists' perceived crowding
}

\author{
S. Mostafa Rasoolimanesh ${ }^{1 *}$, Mastura Jaafar ${ }^{2}$, Azizan Marzuki ${ }^{3}$ \\ and Shardy Abdullah ${ }^{4}$
}

Received: 09/06/2018 Accepted: 12/11/2018

\begin{abstract}
1 School of Hospitality, Tourism, and Events, Taylor's University, 47500, Subang Jaya, Malaysia, Tel: 006-0356295420. E-mail: rasooli1352@yahoo.com; mostafa.rasoolimanesh@taylors.edu.my

2 School of Housing, Building, and Planning, Universiti Sains Malaysia, 11800, Minden, Penang, Malaysia. Email: masturaj@usm.my

${ }^{3}$ School of Housing, Building, and Planning, Universiti Sains Malaysia, 11800, Minden, Penang, Malaysia. Email: chik72@usm.my

${ }^{4}$ Infrastructure and asset management office, Universiti Malaysia Kelantan, Bachok Campus, Locked Bag No 1, 16300 Bachok, Kelantan, Malaysia. E-mail: shardy.a@umk.edu.my

* Corresponding author
\end{abstract}

Coordinating editor: Stanislav Ivanov

\section{Abstract}

This paper investigates the effects of personal factors and travel characteristics on tourists' perceived crowding of Kilim Geopark, Langkawi Island, Malaysia. There are paucity of studies in the literature to investigate the influencing factors on perceived crowding, including personal factors and travel characteristics. Moreover, we justify, propose and assess both influencing factors and perceived crowding as formative (composite) factors, which has not been a common practice in previous studies. Data for this study was collected during March 2014. To analyze the proposed relationships, this study uses partial least squares-structural equation modeling (PLS-SEM). The results show a significant effect for age, education, and income level on perceived crowding. In addition, the findings support the effects of motivation and travel characteristics on perceived crowding. However, the results of this study do not support the effects of nationality, gender, or destination familiarity on perceived crowding. This study has a number of theoretical and methodological contributions. Moreover, the results can assist Langkawi Island's local authorities to understand the perceptions of tourists, and increase their satisfaction.

Keywords: Perceived crowding, personal factors, travel characteristics, Langkawi Island, partial least squares - structural equation modeling (PLS-SEM)

Citation: Rasoolimanesh, S. M., M. Jaafar, A. Marzuki and S. Abdullah (2019) Examining the effects of personal factors and travel characteristics on tourists' perceived crowding. European Journal of Tourism Research 22, pp. 5-19

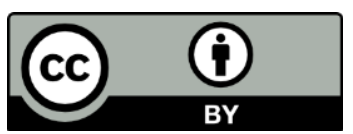

RESEARCH PAPER
This work is licensed under the Creative Commons Attribution 4.0 International (CC BY 4.0). To view a copy of this license, visit https://creativecommons.org/licenses/by/4.0/ 


\section{Introduction}

Increasing tourist numbers and maximizing their satisfaction are important concerns for management and development of a tourism destination. Addressing these issues is largely dependent on understanding the travel experiences of tourists and their perceptions of the destination itself (Pike \& Ryan, 2004; Tapachai \& Waryszak, 2000). Previous studies have highlighted tourists' perceptions of destination crowding as a significant factor in encouraging or discouraging them from revisiting a destination or suggesting a destination to other people (Jurado et al., 2013; Neuts \& Nijkamp, 2012). According to consumer behavior theory, factors likely to have a significant effect on tourists' perceptions of a destination include: (a) personal and sociopsychological factors, such as sociodemographic characteristics (e.g., nationality, gender, age, education, and level of income) (Beerli \& Martin, 2004a, 2004b; Fleishman et al., 2004; Jurado et al., 2013); (b) familiarity with the destination and previous tourism experiences (Getz, 1983; Jurado et al., 2013; Neuts \& Nijkamp, 2012); and (c) motives for visiting a particular destination (Cole \& Stewart, 2002; Lee \& Graefe, 2003; Neuts \& Nijkamp, 2012). Travel characteristics are also likely to influence tourists' attitudes toward destination overcrowding, including the purpose of their visit to a destination (Bellenger \& Korgaonkar, 1980; Lee \& Graefe, 2003; Neuts \& Nijkamp, 2012), length of stay (Jurado et al., 2013; Russo, 2002), and the number of hours and money spent at an attraction (Jurado et al., 2013; Neuts \& Nijkamp, 2012).

Tourism plays a significant role in Malaysia's socioeconomic development, with 25.7 million tourist arrivals in 2013 contributing around USD 21 billion to the local economy (World Tourism Organization [UNWTO], 2014). Rich in natural attractions, Langkawi Island is one of Malaysia's more popular island tourism destinations, attracting millions of international and domestic tourists alike, and aims to be counted among the world's top ten most popular island and ecotourism destinations. In evidence of Langkawi's growing popularity as a tourism destination, the Langkawi Development Authority (2014) notes that Langkawi Island received 3.41 million visitors in 2013 alone, having hosted 2.30 million tourist arrivals in 2008.

Kilim Geopark, one of Langkawi's more popular tourism attractions, serves as the setting for the current study. Kilim Geopark hosts a number of geological heritage sites, such as narrow valleys, tropical trees, mangrove forests, and ancient limestone formations, including caves (Yacob et al., 2013) of international significance, thus making it an ideal ecotourism destination. However, maintaining the geopark's delicate ecosystem means having to limit the expansion of the infrastructure (e.g., accommodation, recreational services, retail outlets, etc.) that would normally be expected of a rapidly developing and high capacity tourism destination. Moreover, visitors to ecotourism destinations expect a certain level of isolation from other tourists (Boyd \& Butler, 1996). Therefore, understanding tourists' perceptions of crowding at Kilim Geopark is important in terms of ensuring the sustainability of local tourism services.

Few studies have examined the effects of personal factors and travel characteristics on tourists' perceptions of crowding (Beerli \& Martin, 2004a; Jurado et al., 2013). Therefore, this study makes a significant contribution to the literature concerning tourists' perceived crowding. In addition, this study aims to make a significant methodological contribution to the literature through the use of partial least squares-structural equation modeling (PLSSEM) to assess the relationships between the formative (composite) influencing factors and the tourist perceived crowding construct.

Therefore, this study aims to explore the perceived crowding of tourists visiting Kilim Geopark, in Langkawi Island, and to investigate the effects of visitors' sociodemographic characteristics, familiarity with the destination, motivation for visiting the destination, and travel characteristics on tourists' perceived crowding using PLS-SEM. In the next section, this paper explores the crowding and carrying capacity literature, before reviewing the factors influencing perceived crowding. Following the literature review are the methodology, results of analysis, and discussion sections. This paper concludes with an outline of the practical 
implications of these findings, identifies some of the limitations of this research, and makes recommendations for future research.

\section{Tourists' Perceived Crowding}

Crowding refers to the level of saturation of a destination (Jurado et al., 2013), and can be considered from environmental and sociopsychological perspectives (Saveriades, 2000). The environmental perspective, which is referred in terms of carrying capacity, is concerned with the number of visitors that a destination can sustain at any one time without causing damage to the physical, economic, or sociocultural environment (Coccossis et al., 2002). The sociopsychological perspective, however, holds crowding to be a subjective experience, identifiable from the perspectives and experiences of tourists (Neuts \& Nijkamp, 2012). Therefore, irrespective of actual tourist density, tourists will become dissatisfied and potentially look for alternative destinations if they perceive a destination to be crowded (Jurado et al., 2013). Consequently, perceived destination crowding and carrying capacity are often investigated concurrently.

\section{Baud-Bovy and Lawson (1977) define} recreational carrying capacity as, "the number of user-unit, use-periods, that a recreation site can provide without permanent biological and physical deterioration of the site's ability to support recreation and without appreciably impairing the quality of the recreation experience" (p. 184). This definition is not dissimilar to that offered more recently by the UNWTO, who define tourism carrying capacity as, "the maximum number of people that may visit a tourist destination at the same time without causing destruction of the physical, economic or sociocultural environment and an unacceptable decrease in the quality of the tourist satisfaction" (Coccossis et al., 2002, p. 38 ). What these definitions share in common is a concern for the number of tourists that can be attracted to a destination as opposed to the willingness of tourists to travel to the destination (O'Reilly, 1986). Moreover, these definitions imply a threshold for a destination's visitor volume. Overcrowding, therefore, is the state of having crossed this threshold. Nonetheless, how the benchmark for this threshold should be established, and the subsequent level of destination crowding, is something for which there is little in the way of scholarly consensus (Saveriades, 2000).

Sociopsychological perspectives, alternatively, explain perceived crowding in terms of tourists' expectations and experiences (Jurado et al., 2013; Rasoolimanesh et al., 2017b). A destination's threshold for visitor crowding varies according to the perceptions and satisfaction of tourists. Therefore, a tourist's decision as to which destination to visit or revisit, and their choice to recommend that destination to their friends is based upon their travel experiences and subsequent perceptions of a destination (Pike \& Ryan, 2004; Tapachai \& Waryszak, 2000). Consequently, local authorities are curious to understand why tourists choose to visit a particular destination or why they might ignore it (Wong \& Yeh, 2009). Several studies have reported that tourists' perceptions of crowding contribute toward the formation of their intentions to visit a destination (Jurado et al., 2013; Neuts \& Nijkamp, 2012). Moreover, perceived crowding contributes toward a destination's image, this image informing subsequent tourist decisionmaking and behaviors (Pike \& Ryan, 2004; Tapachai \& Waryszak, 2000).

\section{Personal Factors and Perceived Crowding}

Several factors influence tourists' perceptions of crowding at a destination. Previous studies suggest that tourists' perceptions of destination crowding are mediated by a host of sociodemographic characteristics, such as the nationality of the tourist, their gender, age, education level, and level of income (Beerli \& Martin, 2004a, 2004b; Fleishman et al., 2004; Hayduk, 1985; Jurado et al., 2013; Rasoolimanesh et al., 2016; Yagi \& Pearce, 2007). Moreover, consumer behavior theory would suggest that individual factors, such as the tourist's sociodemographic characteristics and sociopsychological factors (e.g., motivation, value, beliefs, and lifestyle) play a significant role in determining tourists' perceptions of a destination (Beerli \& Martin, 2004b; Rasoolimanesh et al., 2016; Um \& Crompton, 1992). To illustrate this point, in a study of perceived crowding of a tourism destination, Jurado et al. (2013) reported a significant effect for tourists' nationality, age, 
education, and level of income. Likewise, Neuts and Nijkamp (2012) reported on perceived crowding among tourists to Bruges in Belgium, and found that tourists' perceptions of crowding varied significantly according to the nationality of the tourist. Therefore, for the purpose of this study the following hypotheses are articulated based on the previous literature:

H1: Nationality has a significant effect on tourists' perceived crowding in Kilim Geopark.

H2: Gender has a significant effect on tourists' perceived crowding in Kilim Geopark.

H3: Age has a significant effect on tourists' perceived crowding in Kilim Geopark.

H4: Level of education has a significant effect on tourists' perceived crowding in Kilim Geopark.

H5: Level of income has a significant effect on tourists' perceived crowding in Kilim Geopark.

Along the line of consumer behavior theory, this study investigates two additional personal factors thought to exert a significant influence on the perceived crowding of tourist destinations: tourist's familiarity with the destination, and tourists' motivations for visiting a destination. Previous studies have explored the effects of familiarity in regard to perceived crowding of tourist destinations (Getz, 1983; Jurado et al., 2013; Neuts \& Nijkamp, 2012). In this study, two factors are used to measure tourists' familiarity with the destination: (a) number of visits to Langkawi Island, and (b) number of visits to Kilim Geopark. The following hypotheses represent the effects of these items on tourists' perceived crowding:

H6: The number of visits to Langkawi Island has a significant effect on tourists' perceptions of crowding.

H7: The number of visits to Kilim Geopark has a significant effect on tourists' perceptions of crowding.

The effect of tourists' motivations for visiting a destination on their perceived crowding has been investigated through several studies (Cole \& Stewart, 2002; Lee \& Graefe, 2003; Neuts \& Nijkamp, 2012). Tourists perceive crowding at a destination depending on their motives for visiting the destination and their expectations of the destination. The current study conceptualizes tourists' motivations under three factors: (a) reasons for choosing to visit the destination, (b) aspects the tourists like in the destination, and (c) aspects the tourist dislikes in the destination. Therefore, the following three hypotheses indicate the effects of motivation on tourists' perceived crowding in Kilim Geopark:

H8: Tourists' reasons for choosing to visit Kilim Geopark has a significant effect on their perceptions of crowding.

H9: Aspects that the tourists like about Kilim Geopark has a significant effect on their perceptions of crowding.

H10: Aspects that the tourists dislike about Kilim Geopark has a significant effect on their perceptions of crowding.

\section{Travel Characteristics and Perceived Crowding}

Several studies have indicated that tourist's perceptions of destination crowding are mediated by a range of factors related to their trip and travel characteristics. These factors include: (a) the purpose of the tourist's visit to the destination (Bellenger \& Korgaonkar, 1980; Lee \& Graefe, 2003; Neuts \& Nijkamp, 2012), (b) length of stay (Jurado et al., 2013; Russo, 2002), and (c) the number of hours and money spent at an attraction (Jurado et al., 2013; Neuts \& Nijkamp, 2012). Therefore, the following hypotheses are designed to explore the effects of these travel characteristics on tourists' perceived crowding of Kilim Geopark:

H11: The purpose of a tourist's visit has a significant effect on their perceived crowding of Kilim Geopark.

H12: The tourist's length of stay has a significant effect on their perceived crowding of Kilim Geopark.

H13: The number of hours spent in Kilim Geopark has a significant effect on tourists' perceived crowding of Kilim Geopark.

H14: The amount of money spent in Kilim Geopark has a significant effect on tourists' perceived crowding of Kilim Geopark.

The conceptual framework used for the current study is illustrated in Figure 1. 


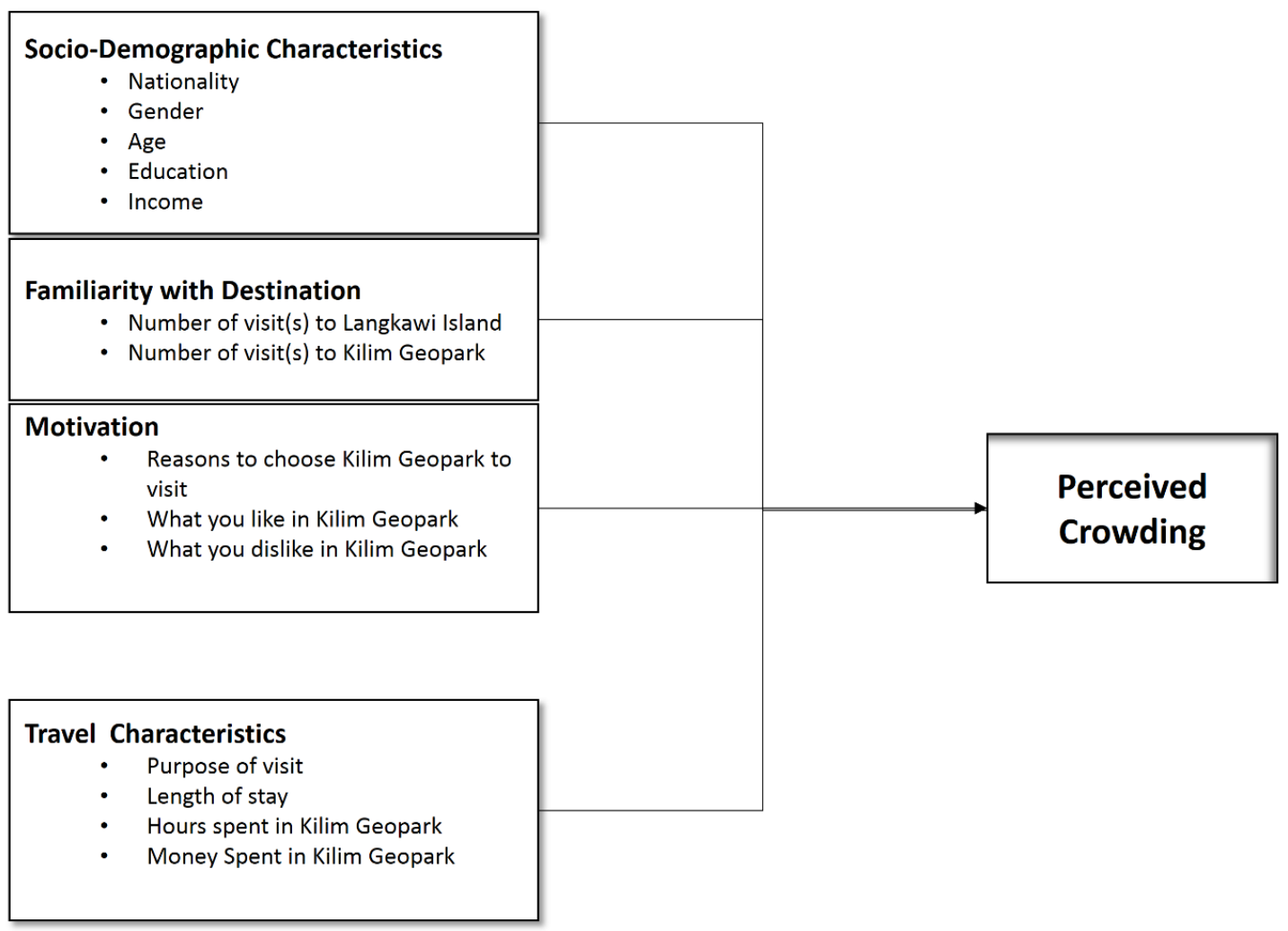

Figure 1. Conceptual framework

\section{Kilim Geopark, Langkawi Island}

Kilim Geopark is one of Langkawi Island's more popular tourist attractions. The mangrove forests, limestone caves, narrow valleys and tunnels, and tropical trees make Kilim Geopark a uniquely attractive destination of choice for many of Langkawi's visitors (Yacob et al., 2013). Along with boosting overall tourist arrivals to Langkawi, the geopark itself has seen a sharp increase in the number of tourist arrivals from 78,145 in 2007 to 159,338 in 2011 (Kilim Community Cooperative Society [KCCS], 2012).

Kilim Geopark offers a variety of ecotourism products, and each tour package covers a different locality and lasts 1-4 hours. Tour packages include visits to the crocodile cave, bat cave, floating fish farm, floating restaurant, fishing trips, open sea viewing, fish feeding, eagle feeding, mangrove sightseeing, and others. In addition to having the chance to enjoy Kilim Geopark's pristine and unique natural beauty, sightseeing packages afford the 10 visitor the opportunity to discover Kilim's unique ecosystems, culture, and history (Jaafar et al., 2014; Yacob et al., 2013).

\section{Research Methodology}

Data for this quantitative study was collected using a self-administered questionnaire divided into three parts. Respondents' sociodemographic characteristics, such as their nationality, age, gender, education level, and monthly income was collected in the first part of the questionnaire. The second part of the questionnaire asked a range of questions intended to identify respondent's familiarity with the destination, motives for choosing to visit Langkawi Island and Kilim Geopark, and their travel characteristics. The familiarity subsection of the questionnaire addressed two factors: (a) the number of visits to Langkawi Island, and (b) the number of visits to Kilim Geopark. The motivation subsection involved three factors: (a) the respondent's reasons for choosing to visit Kilim Geopark, (b) what aspects the respondent liked at Kilim Geopark, and (c) what 
aspects the respondents disliked at Kilim Geopark. The travel and trip characteristics subsection enquired as to the purpose of the respondent's visit, their length of stay, hours spent in Kilim Geopark, and how much money they spent in Kilim Geopark.

Dichotomous questions were used to facilitate the measurement of items in this second part of the questionnaire. Respondents were required to indicate their responses to these questions using simple "yes" or "no" answers. The questions themselves formed the factors under investigation and the questions associated with these factors were not correlated with one another; therefore, these factors constitute formative constructs (Hair et al., 2017). This part of the questionnaire was developed based on similar instruments used originally by Jurado et al. (2013) and Neuts and Nijkamp (2012), but was expanded upon considerably by the researchers to cover a broader range of activities possible in Kilim Geopark.

The third part of the questionnaire was concerned with respondent's perceptions of destination crowding and developed based on similar questions used previously by Jurado et al. (2013) and Neuts and Nijkamp (2012). The current study sought to determine respondents' perceptions of crowding during different activities, including the number of tourists present during mangrove tours, the number of swimmers, and the number of participants in water-activities. Therefore, the perceived crowding construct included three question items in reference to a range of popular activities often performed within the vicinity of Kilim Geopark. The perceived level of crowding during these activities was measured on a 4point Likert scale, with 1 denoting not at all crowded and 4 denoting extremely crowded.

The respondents to this survey were tourists visiting within the vicinity of Kilim Geopark during March of 2014. The questionnaires were administered in English and Bahasa Malay languages. A number students of the Universiti Sains Malaysia were involved in administering the questionnaires to visiting tourists. The students approached tourists within the Kilim Geopark at random, and if the tourist consented, the student interviewed them to complete the questionnaires. Malaysian tourists were administered the Bahasa Malay version of the questionnaire, while international tourists were administered the English version. This method of data collection led to 182 questionnaires in total having been completed.

The relationships proposed in this study were examined using PLS-SEM, a comprehensive statistical approach that can simultaneously evaluate and modify a conceptual model, including the relationships among the variables. PLS-SEM was the preferred method of analysis given that the framework of this study contained a number of formative constructs (Hair et al., 2017). WarpPLS 5.0 (Kock, 2015) was used to analyze the data and to perform the PLS-SEM analysis. To assess the adequacy of data using PLS-SEM in this study, we used $G^{*}$ Power software, and calculated the minimum sample size (Faul et al., 2009; Hair et al., 2017). The results of $G^{*}$ Power for 14 predictors showed the required minimum sample size of 135 for this study to get the power of 0.80 for the analysis. Therefore, the total number of 182 questionnaires should be enough to perform analysis in this study.

\section{Analysis and Findings \\ Descriptive Analysis}

The sociodemographic characteristics of the respondents are reported in Table 1 . Of the 182 respondents to this study, $80.8 \%$ were Malaysian, while the remaining $19.2 \%$ were from other countries. Just over half of the respondents were male $(50.5 \%)$ and $49.5 \%$ were female. The respondents were categorized into five age groups, with 16-25 years olds comprising the largest cohort $(41.8 \%)$. Most of the respondents had completed some form of tertiary education, with $24.2 \%$ holding a diploma and $25.3 \%$ having graduated from some other form of higher education. Table 1 also shows that respondents varied considerably in terms of their monthly income, with $34.1 \%$ earning less than USD 500 and $22.5 \%$ earning in excess of USD 3000 per month.

As indicated in Table 2, most of respondents (60.4\%) had visited Langkawi Island more than once previously; however, for many (58.3\%), this was their first time visiting Kilim Geopark. 
Table 1. Profile of the respondents

\begin{tabular}{|c|c|c|}
\hline Characteristics & Frequency & $\begin{array}{c}\text { Percentage } \\
\text { (\%) }\end{array}$ \\
\hline $\begin{array}{l}\text { Nationality } \\
\text { Malaysian } \\
\text { Non-Malaysian }\end{array}$ & $\begin{array}{l}147 \\
35\end{array}$ & $\begin{array}{l}80.8 \\
19.2\end{array}$ \\
\hline $\begin{array}{l}\text { Gender } \\
\text { Male } \\
\text { Female }\end{array}$ & $\begin{array}{l}92 \\
90\end{array}$ & $\begin{array}{l}50.5 \\
49.5\end{array}$ \\
\hline $\begin{array}{l}\text { Age (Years) } \\
16-25 \\
26-35 \\
36-45 \\
46-55 \\
56 \text { and above }\end{array}$ & $\begin{array}{l}76 \\
36 \\
34 \\
18 \\
18\end{array}$ & $\begin{array}{l}41.8 \\
19.8 \\
18.7 \\
9.9 \\
9.9\end{array}$ \\
\hline $\begin{array}{l}\text { Level of Education } \\
\text { No formal education } \\
\text { Primary school } \\
\text { Secondary school } \\
\text { Certificate/Diploma } \\
\text { Higher Education } \\
\text { (Degree/Master/PhD) }\end{array}$ & $\begin{array}{l}12 \\
25 \\
55 \\
44 \\
46\end{array}$ & $\begin{array}{l}6.5 \\
13.8 \\
30.2 \\
24.2 \\
25.3\end{array}$ \\
\hline $\begin{array}{l}\text { Level of Income } \\
\text { Under USD } 500 \\
\text { USD 500-1000 } \\
\text { USD } 1000-1500 \\
\text { USD 1500-3000 } \\
\text { Above USD } 3000 \\
\text { Missing value }\end{array}$ & $\begin{array}{l}62 \\
28 \\
12 \\
27 \\
41 \\
12\end{array}$ & $\begin{array}{l}34.1 \\
15.4 \\
6.6 \\
14.8 \\
22.5 \\
6.6 \\
\end{array}$ \\
\hline
\end{tabular}

Most of respondents (75.8\%) were visiting Kilim Geopark for the purposes of leisure, recreation, or a holiday. The remaining $24.2 \%$ of respondents were visiting Kilim Geopark for educational purposes, visiting friends and family, or to attend some kind of an event. The majority of the respondents were staying on Langkawi Island for periods ranging 3-7 days $(62.6 \%)$, and most spent $1-3$ hours per day in Kilim (65.4\%). Also, most of the respondents spent less than MYR 50 (USD 1 equals MYR 4.20 , at the time of this writing) per day in the geopark $(52.8 \%)$. Additionally, most of the respondents indicated having chosen to visit Kilim Geopark because of the "nature and landscape" (78\%). Respondents looked forward to "good facilities" $(29.1 \%)$, a "relaxedfriendly atmosphere" (23.6\%), and "good weather" $(22.5 \%)$. What the respondents hoped to avoid seeing were "poor facilities" (23.6\%), "crowdedness" (23.6\%), and "litter on sand" (20.9\%).

Table 3 indicates that most of respondents perceived Kilim Geopark to be crowded.
Respondents indicated the greatest degree of crowding in the "number of mangrove tour participants," followed by the "number of waterbased activity participants," and the "number of swimmers."

\section{Assessment of Framework using PLS-SEM}

To assess a framework using PLS-SEM, we followed a two-step process involving assessment of the measurement and structural models respectively (Chin, 2010; Hair et al., 2011). Assessing the measurement model involves having to test the relationships between constructs and their associated items. Conversely, the structural model assessment involves an examination of the relationships between the constructs.

\section{Assessment of Measurement Model}

The framework of the current study includes fourteen factors: nationality, gender, age, education, income, number of visit(s) to Langkawi Island, number of visit(s) to Kilim Geopark, reasons to choose Kilim Geopark, what the tourist likes about Kilim Geopark, what the tourist dislikes about Kilim Geopark, the purpose of their visit, length of stay, hours spent in Kilim Geopark, and money spent in Kilim Geopark. Ten of these factors were measured though a single item, while the remaining four factors were measured using multiple question items. The four multi-item factors are considered formative or composite constructs because measurement of the factors is contingent upon all of these items being measured together and on the question items for each constructs not being interchangeable. Moreover, perceived crowding constitutes a formative construct. Therefore, in the framework of the current study there are ten single item construct and five formative constructs.

To assess the formative constructs, the Variance Inflated Factor (VIF), or the collinearity of the items associated with the formative construct should be less than 5 and the outer weight of the items should be significant (Ali et al., 2018; Chin, 2010; Hair et al., 2017). Table 4 shows the results of the assessment of the five formative constructs included in the measurement model (i.e., purpose of visit, reasons for choosing the 
Table 2. The results of descriptive analysis

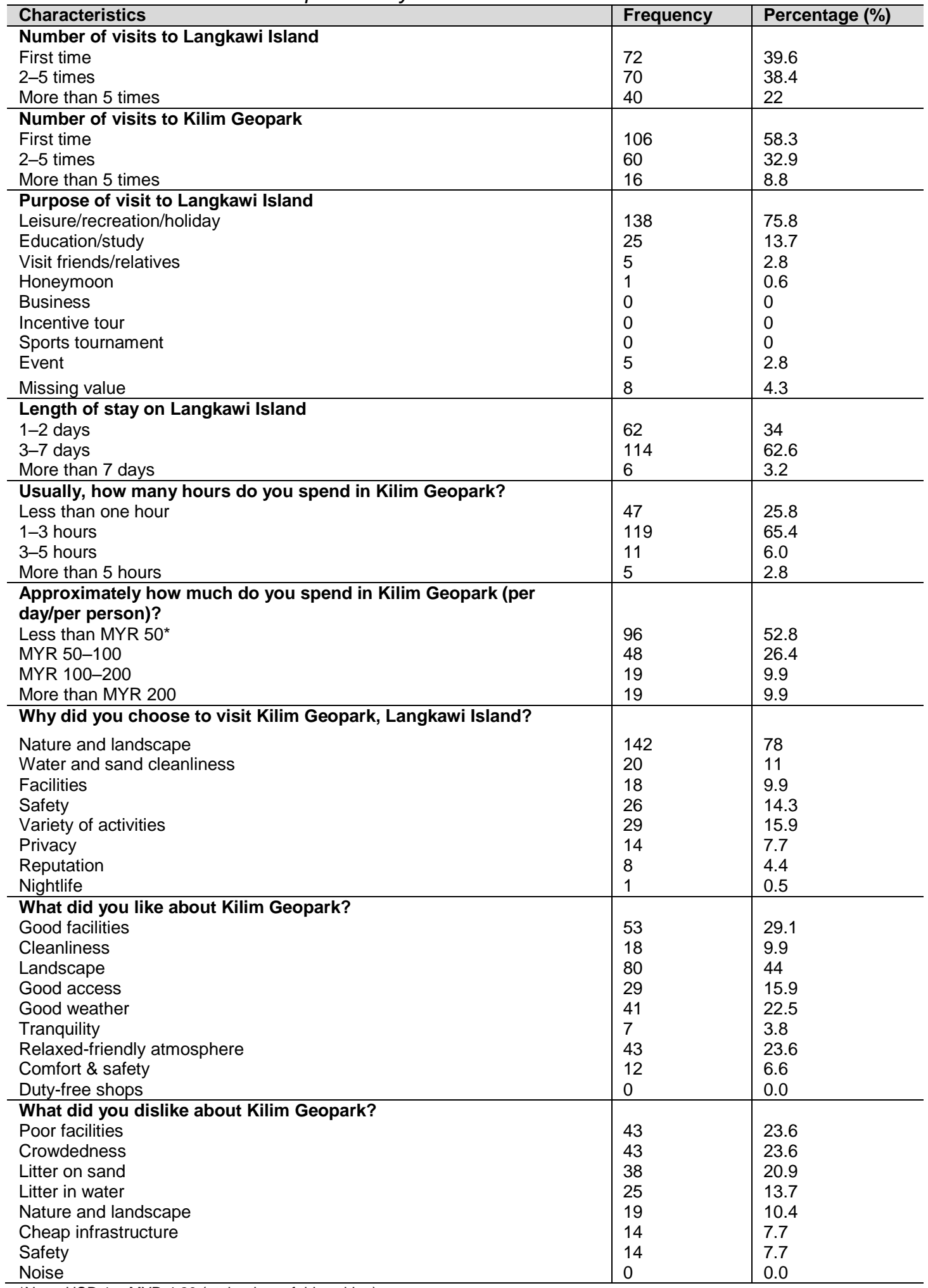

\footnotetext{
${ }^{*}$ Note: USD 1 = MYR 4.20 (at the time of this writing)
} 
Table 3. Results of descriptive analysis of perceived crowding

\begin{tabular}{lll}
\hline \multicolumn{1}{c}{ Items } & Mean value & Standard Deviation \\
\hline Perceived Crowding & & \\
Number of mangroves tour participants & 2.25 & 0.91 \\
Number of swimmers & 2.02 & 0.91 \\
Number of water-based activity participants & 2.17 & 0.89 \\
\hline
\end{tabular}

Table 4. Results of the assessment of measurement model

\begin{tabular}{|c|c|c|c|c|c|}
\hline Construct & Items & Weights & $P$ value & VIF & $\begin{array}{c}\text { Full } \\
\text { Collinearity }\end{array}$ \\
\hline \multirow[t]{6}{*}{ Purpose of travel } & & & & & 1.42 \\
\hline & Leisure/recreation/holiday & 0.543 & $<0.01$ & 4.41 & \\
\hline & Education/study & 0.458 & $<0.01$ & 3.56 & \\
\hline & Visit friends/relatives & 0.159 & $<0.01$ & 1.58 & \\
\hline & Honeymoon & 0.068 & 0.130 & 1.12 & \\
\hline & Event & 0.161 & $<0.01$ & 1.58 & \\
\hline \multicolumn{4}{|c|}{ Reasons for choosing Kilim Geopark } & & 1.23 \\
\hline & Nature and landscape & 0.009 & 0.444 & 1.251 & \\
\hline & Water and sand cleanliness & 0.070 & 0.118 & 1.189 & \\
\hline & Facilities & 0.484 & $<0.01$ & 1.128 & \\
\hline & Safety & 0.442 & $<0.01$ & 1.119 & \\
\hline & Variety of activities & 0.216 & $<0.01$ & 1.087 & \\
\hline & Privacy & 0.237 & $<0.01$ & 1.069 & \\
\hline & Reputation & 0.044 & 0.232 & 1.151 & \\
\hline & Nightlife & 0.376 & $<0.01$ & 1.11 & \\
\hline \multicolumn{5}{|c|}{ What did the tourists like in Kilim } & 1.34 \\
\hline & Good facilities & 0.533 & $<0.01$ & 1.18 & \\
\hline & Cleanliness & 0.290 & $<0.01$ & 1.05 & \\
\hline & Landscape & 0.442 & $<0.01$ & 1.18 & \\
\hline & Good access & 0.313 & $<0.01$ & 1.04 & \\
\hline & Good weather & 0.094 & 0.05 & 1.09 & \\
\hline & Tranquility & 0.163 & $<0.01$ & 1.10 & \\
\hline & Relaxed/friendly atmosphere & 0.151 & $<0.01$ & 1.05 & \\
\hline & Comfort \& safety & 0.044 & 0.233 & 1.03 & \\
\hline \multicolumn{5}{|c|}{ What did the tourists dislike in Kilim } & 1.24 \\
\hline & Poor facilities & 0.525 & $<0.01$ & 1.13 & \\
\hline & Crowdedness & 0.310 & $<0.01$ & 1.11 & \\
\hline & Litter on sand & 0.240 & $<0.01$ & 1.02 & \\
\hline & Litter in water & 0.330 & $<0.01$ & 1.06 & \\
\hline & Nature and landscape & 0.192 & $<0.01$ & 1.05 & \\
\hline & Cheap infrastructure & 0.279 & $<0.01$ & 1.04 & \\
\hline & Safety & 0.248 & $<0.01$ & 1.05 & \\
\hline \multirow[t]{4}{*}{ Perceived Crowding } & & & & & 1.21 \\
\hline & $\begin{array}{l}\text { Number of mangroves tour } \\
\text { participants }\end{array}$ & 0.351 & $<0.01$ & 1.70 & \\
\hline & Number of swimmers & 0.387 & $<0.01$ & 2.93 & \\
\hline & $\begin{array}{l}\text { Number of water-based } \\
\text { activity participants }\end{array}$ & 0.391 & $<0.01$ & 3.08 & \\
\hline
\end{tabular}

destination, what the tourist likes, what the tourist dislikes, and their perceptions of crowding) (N.B. single item constructs have been excluded from this stage of analysis). The VIFs of all associated formative construct indicators was less than 5 and the outer weight $P$ values for most of items was less than 0.05 and significant. According to Table 4, six of the items used for the construction of the measurement model had non-significant outer weights. If these items are to be retained, the outer loadings of these items should be significant; otherwise, these items should be discarded from the model (Chin, 2010; Hair et 
al., 2011). In this case, with the exception of the "nature and landscape" item belonging to the "reasons for choosing the destination" construct, the outer loadings of all the items were significant; therefore, these items were retained. Looking again at Table 2 , the "nature and landscape" item is instrumental to the formation of the "reasons for choosing the destination" construct, with $75.8 \%$ of respondents acknowledging this to be the reason for their visit to Kilim Geopark. Therefore, in light of the relative importance of this item, it cannot be removed from the model. If expert opinion and empirical testing attest to the relevance of an item to a construct, the item can be retained despite the non-significance of the outer weight and outer loading (Hair et al., 2017); thus the item has been retained for further analysis.

Another important criterion necessary to complete the assessment of a measurement model, especially when the model includes formative constructs, is the collinearity of the constructs (Hair et al., 2017; Rasoolimanesh et al., 2017a). WarpPLS 5.0 calculates full collinearity, referring to the vertical and lateral collinearity of one construct in relation to other constructs (Kock \& Lynn, 2012). This measure should be less than 5 (Hair et al., 2014). As indicated in Table 4, the full collinearity of all the constructs was less than 5 . Therefore, the results indicate the acceptability of the measurement model for the five formative constructs.

\section{Assessment of Structural Model}

To assess the structural model and test the proposed hypotheses using PLS-SEM, at least two criteria should be considered and interpreted, the R-square $\left(R^{2}\right)$ measure for the endogenous constructs and the path coefficients (Ali et al., 2018; Chin, 2010; Hair et al., 2011). The path coefficients must be significant; however, the value of $\mathrm{R}^{2}$ can vary depending on the research area. Chin (2010) suggested values of $0.67,0.33$, and 0.19 as measures for $R^{2}$ to be considered respectively substantial, moderate, and weak. Consumer behavior studies consider an $R^{2}$ value of 0.2 a high measure (Hair et al., 2017). In this study, the $R^{2}$ value was 0.17 , and was relatively high by consumer behavior research standards (Kock, 2013).

Table 5 and Figure 2 show the results of path coefficient and hypotheses testing. Table 5 shows that the sociodemographic variables of

Table 5. Results of hypothesis testing

\begin{tabular}{|c|c|c|c|c|}
\hline & Hypothesis & $\begin{array}{l}\text { Path } \\
\text { Coefficient }\end{array}$ & $p$-value & Supported \\
\hline $\mathrm{H} 1$ & Nationality $\rightarrow$ Perceived Crowding & 0.035 & 0.281 & No \\
\hline $\mathrm{H} 2$ & Gender $\rightarrow$ Perceived Crowding & -0.011 & 0.431 & No \\
\hline H3 & Age $\rightarrow$ Perceived Crowding & -0.142 & 0.01 & Yes \\
\hline $\mathrm{H} 4$ & Education $\rightarrow$ Perceived Crowding & 0.100 & 0.05 & Yes \\
\hline H5 & Income $\rightarrow$ Perceived Crowding & 0.150 & $<0.01$ & Yes \\
\hline $\mathrm{H} 6$ & $\begin{array}{l}\text { Number of visit(s) to Langkawi Island } \rightarrow \text { Perceived } \\
\text { Crowding }\end{array}$ & -0.010 & 0.435 & No \\
\hline $\mathrm{H} 7$ & $\begin{array}{l}\text { Number of visit(s) to Kilim Geo park } \rightarrow \\
\text { Perceived Crowding }\end{array}$ & 0.095 & 0.06 & No \\
\hline $\mathrm{H} 8$ & $\begin{array}{l}\text { Reasons to choose Kilim Geo park to visit } \rightarrow \\
\text { Perceived Crowding }\end{array}$ & -0.104 & $<0.05$ & Yes \\
\hline H9 & What the tourists like in Kilim $\rightarrow$ Perceived Crowding & 0.087 & 0.077 & No \\
\hline $\mathrm{H} 10$ & $\begin{array}{l}\text { What the tourists dislike in Kilim } \rightarrow \text { Perceived } \\
\text { Crowding }\end{array}$ & 0.286 & $<0.01$ & Yes \\
\hline $\mathrm{H} 11$ & Purpose of visit $\rightarrow$ Perceived Crowding & 0.089 & 0.072 & No \\
\hline $\mathrm{H} 12$ & Length of stay $\rightarrow$ Perceived Crowding & -0.017 & 0.389 & No \\
\hline $\mathrm{H} 13$ & $\begin{array}{l}\text { Hours spent in Kilim Geo park } \rightarrow \\
\text { Perceived Crowding }\end{array}$ & -0.111 & $<0.05$ & Yes \\
\hline $\mathrm{H} 14$ & $\begin{array}{l}\text { Money Spent in Kilim Geo park } \rightarrow \\
\text { Perceived Crowding }\end{array}$ & -0.103 & $<0.05$ & Yes \\
\hline
\end{tabular}




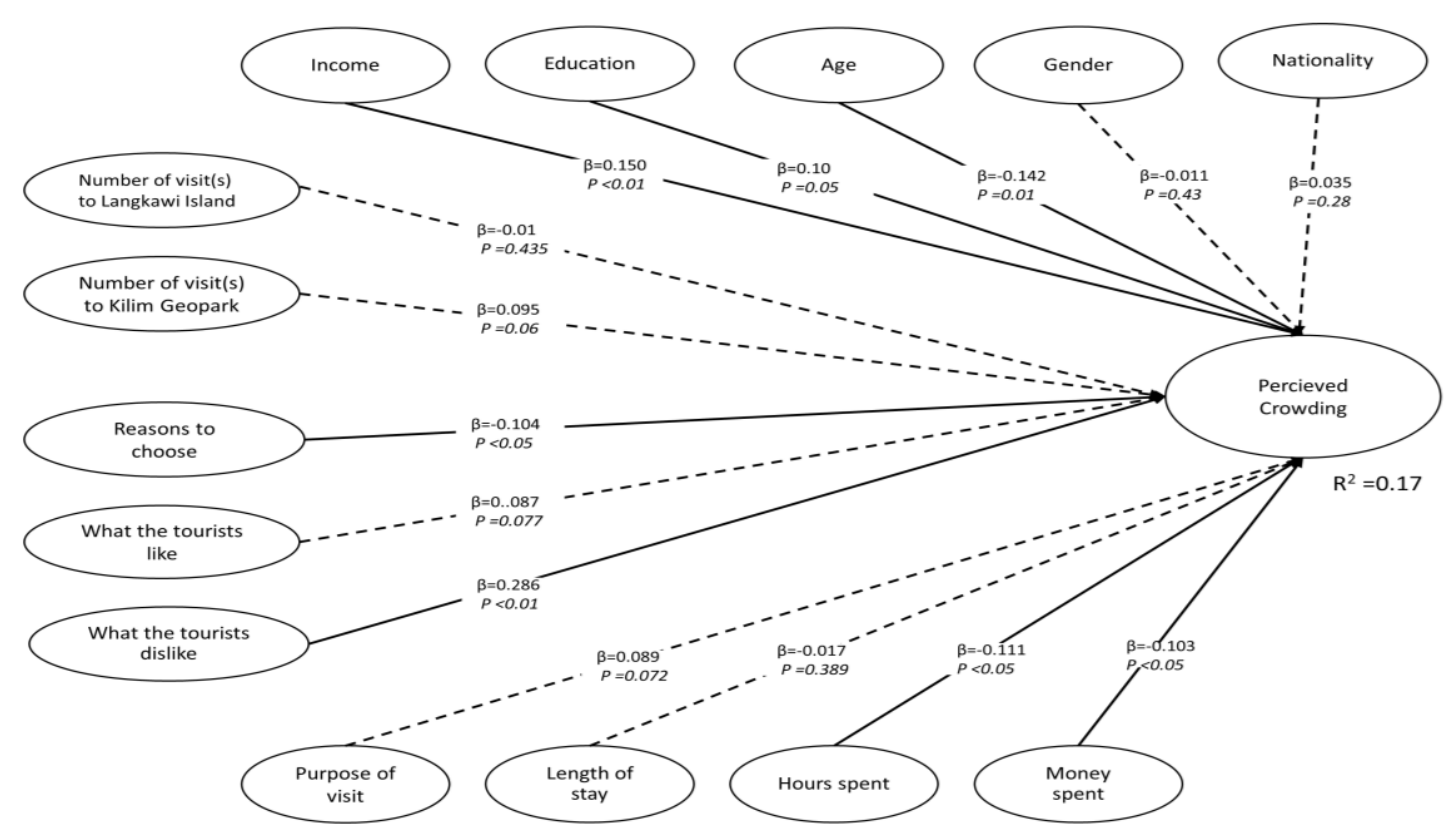

Figure 2. Results of assessment of structural model

age, education, and income exert a significant effect on perceived crowding among the respondent visitors to Kilim Geopark. Among the sociodemographic characteristics, age had a negative effect on perceived crowding, while education and income had positive effects. The results show a non-significant effect for nationality and gender on perceived crowding. The relationship between familiarity, as represented by the number of visits to Langkawi and Kilim, and perceived crowding was similarly non-significant in this study. As seen in Table 5, most of dimensions of motivation exerted a significant effect on perceived crowding. Also, "reasons for choosing Kilim," and "what the tourist disliked," had significant effects on perceived crowding; whereas, "what the tourist liked" had a nonsignificant effect.

Among the travel characteristic factors, "money spent in Kilim," and "hours spent in Kilim," had a significant and negative effect on perceived crowding. No significant effect was found in this study for "length of stay," or "purpose of visit."

\section{Discussion}

This study attempted to examine the effects of personal factors, including visitors' sociode16 mographic characteristics, destination familiarity, motivations for visiting the destination, and travel characteristics on tourists' perceived crowding of a popular tourism destination on Langkawi Island, Malaysia. The findings of this study reveal a non-significant effect for nationality on perceived crowding. Previous studies have attested to the mitigating role of the tourist's cultural background on their perceived crowding of tourism destinations, suggesting a significant effect for nationality on perceived crowding (Neuts \& Nijkamp, 2012; Yagi \& Pearce, 2007). Nonetheless, the findings of current study conflict with these earlier studies. The profile of respondents (see Table 1) shows that over $80 \%$ of the respondents were domestic Malaysian tourists, with just $20 \%$ being international tourists. Few of the tourists who responded to this study came from markedly different cultures, which may explain the non-significant effect of nationality on perceived crowding in our results.

The results also showed a non-significant effect for gender on perceived crowding. Several previous studies have observed a significant effect for gender on tourists' perceptions of 
crowding (Beerli \& Martin, 2004a, 2004b; Saveriades, 2000). However, the findings of the current study do not support a positive effect for gender on perceived crowding, and are thus inconsistent with the findings of previous studies.

The results of $\mathrm{H} 3$ testing reveal a significant and negative effect for age on perceived crowding. The findings indicate that younger tourists perceive more increased level of crowding than older tourists do. This finding suggests that the older tourists to Kilim Geopark were more tolerant of crowding. This finding conflicts with those Jurado et al. (2013), who found that younger tourists were more tolerant of crowding. However, Fleishman et al. (2004) reported having found that younger tourists were less tolerant of crowding. Therefore, the findings of the current study are consistent with study by Fleishman et al. (2004), which similar to the current study had been conducted in two popular nature settings.

Several previous studies have also examined the effects of visitors' level of education and income on their perceived crowding of a destination (Hayduk, 1985; Jurado et al., 2013; Saveriades, 2000). Consistent with the before mentioned studies, the findings of current study show a positive and significant effect of education and level of income on perceived crowding. The results indicate that people from higher income groups who are highly educated are more sensitive to crowding. Jurado et al. (2013) similarly found that high-income tourists tended to be highly sensitive to perceived destination crowding.

The effects of destination familiarity and previous visitor experiences could not be supporting based on the results of this study. Previous studies have identified significant differences between first-time visitor's perceptions of crowding and revisiting tourists who are more familiar with a destination (Getz, 1983; Jurado et al., 2013; Neuts \& Nijkamp, 2012). As indicated in Table 1 , most of the respondents to this survey were domestic Malaysian tourists and were probably already familiar with the destination, regardless of the number of times they had visited. Therefore, the number of visits would be unlikely to impact their familiarity with the destination and or their perceptions of crowding.

This study also investigated the effect of tourists' motivation factors in regard to perceived crowding, finding a significant effect for "reasons to visit" and "what tourists dislike" on perceived crowding. In short, different tourist motivations for visiting a destination and different expectations of the destination led to differences in the perceptions of crowding at Kilim Geopark. Therefore, the results of the current study are consistent with several previous studies that revealed a significant role for motivation on tourists' perceived crowding (Cole \& Stewart, 2002; Lee \& Graefe, 2003; Neuts \& Nijkamp, 2012).

This study, also examined the effects of tourists' travel characteristics, such as the purpose of their visit, length of stay, hours and money spent in a destination. This particular set of results did not support a significant effect for visit purpose on perceived crowding. This finding was inconsistent with the findings of previous studies that report a significant effect for visit purpose on tourists' perceived crowding of specific destinations (e.g. Bellenger \& Korgaonkar, 1980; Lee \& Graefe, 2003; Neuts \& Nijkamp, 2012). In addition, the significant relationship between the number of hours and amount of money spent by tourists at a destination and their perceptions of crowding was supported by the findings of this study. The results showed that this relationship was negative; therefore, tourists who spent more time and money at Kilim Geopark, interacting with other people, perceived less crowding. Such findings are consistent with those of Neuts and Nijkamp (2012). However, the findings of this study did not support the effect of length of stay on the perceived crowding of a destination, something which previous studies (Jurado et al., 2013; Russo, 2002) had confirmed.

\section{Conclusion}

In spite of a focus on carrying capacity and destination crowding in the academic literature since the 1930s, few studies have used the SEM approach to investigate the factors influencing tourists' perceptions of destination crowding. The current study focused on the 
effects of tourist personal factors, from the perspective of consumer behavior theory, and travel characteristics on tourists' perceived crowding. The results showed a significant effect for most of the personal factors and travel characteristics subject to investigation in this study. The perceptions of crowding influences on tourists' satisfaction and their decision to revisit a destination. Therefore, understanding the influencing factors on perceptions of crowding has critical implications for corresponding organizations to manage a destination in a sustainable way while increasing the satisfaction and arrival rate of tourists. Consequently, the findings of this study have practical implications for Langkawi's local authorities and tourism administration, guiding the identification of focus areas for increasing tourists' satisfaction.

Moreover, this study has used PLS-SEM to assess the measurement and structural models, and to test the relationships between the constructs. The factors influencing perceived crowding were single item and formative (composite) constructs, and few met the standard required for normality; therefore, PLS-SEM was the appropriate choice of analysis methods for this study. Having developed and assessed the measurement and structural models by way of PLS-SEM, this study makes a contribution to the literature on this subject.

Nonetheless, because of the difficulties associated with conducting tourism research during peak seasons, this study was conducted during the Kilim Geopark mid-season; as such, the sample size may not have been large enough to generalize the results. Consequently, the results may have been biased, because of the timing and likely less level of crowding in mid-season. The results might have been different, if the study had been conducted during the peak season. In light of this limitation, further studies should be conducted during the peak tourist arrival season and with larger sample sizes in order to arrive at a more generalizable set of results.

Acknowledgement: This project was funded through a research grant from the Ministry of Higher Education, Malaysia under the LongTerm Research Grant Scheme 2011 [LRGS
Grant No. JPT.S (BPKI)2000/09/01/015Jld4 (67)].

\section{References}

Ali, F., Rasoolimanesh, S. M., Sarstedt, M., Ringle, C. M., \& Ryu, K. (2018). An assessment of the use of partial least squares structural equation modeling (PLS-SEM) in hospitality research. International Journal of Contemporary Hospitality Management, 30(1), 514-538.

Arnberger, A., \& Haider, W. (2007). Would you displace? It depends! A multivariate visual approach to intended displacement from an urban forest trail. Journal of Leisure Research, 39 (2), 345.

Beerli, A., \& Martin, J. D. (2004a). Factors influencing destination image. Annals of Tourism Research, 31 (3), 657-681. doi:10.1016/j.annals.2004.01.010

Beerli, A., \& Martín, J. D. (2004b). Tourists' characteristics and the perceived image of tourist destinations: a quantitative analysis-A case study of Lanzarote, Spain. Tourism Management, 25 (5), 623636. doi:10.1016/j.tourman.2003.06.004

Bellenger, D. N., \& Korgaonkar, P. K. (1980). Profiling the recreational shopper. Journal of Retailing, 56 (3), 77-92.

Boyd, S. W., \& Butler, R. W. (1996). Managing ecotourism: an opportunity spectrum approach. Tourism management, 17(8), 557-566.

Chin, W. W. (2010). How to write up and report PLS analyses. In V. E. Vinzi, W. W. Chin, J. Henseler \& H. Wang (Eds.), Handbook of Partial Least Squares. New York, NY: Springer. doi:10.1007/978-3-540-32827829

Cole, D. N., \& Stewart, W. P. (2002). Variability of user-based evaluative standards for backcountry encounters. Leisure Sciences, 24 (3-4), 313-324. doi:10. 1080/ 1490400290050763

Economic Planning Unit (2011). Blueprint Pelancongan Langkawi 2011-2015 [The Langkawi Tourism Blueprint 2011-2015]. Retrieved from http://www.epu.gov.my/en/ blueprint-pelancongan-langkawi-2011-15

Fleishman, L., Feitelson, E., \& Salomon, I. (2004). The role of cultural and demographic diversity in crowding perception: Evidence from nature reserves 
in Israel. Tourism Analysis, 9 (1-2), 2340. doi:10.3727/1083542041437530

Faul, F., Erdfelder, E., Buchner, A. and Lang, A.-G. (2009) 'Statistical power analyses using G*Power 3.1: Tests for correlation and regression analyses', Behavior Research Methods, 41 (4): 1149-60.

Hair, J., Hult, G., Ringle, C., \& Sarstedt, M. (2017). A primer on partial least squares structural equations modeling (PLSSEM)(2nd ed.). Los Angeles, CA: SAGE.

Hair, J. F., Ringle, C. M., \& Sarstedt, M. (2011). PLS-SEM: Indeed a silver bullet. Journal of Marketing Theory and Practice, 19 (2), 139-151. doi:10.2753/MTP10696679190202

Hair J. F., Sarstedt, M.J., Hopkins, L., \& Kuppelwieser, V.G. (2014). Partial least squares structural equation modeling (PLS-SEM) An emerging tool in business research. European Business Review, 26 (2), 106-121. doi:10.1108/EBR-10-20130128

Hayduk, L. A. (1985). Personal space: The conceptual and measurement implications of structural equation models. Canadian Journal of Behavioural Science / Revue Canadienne des Sciences du Comportement, 17 (2), 140. doi:10.1037/ h0080132

Jaafar, M., Nordin, A. O. S., Abdullah, S., \& Marzuki, A. (2014). Geopark Ecotourism Product Development: A Study on Tourist Differences. Asian Social Science, 10 (11), 42. doi:10.5539/ass.v10n11p42

Jurado, E. N., Damian, I. M., \& FernándezMorales, A. (2013). Carrying capacity model applied in coastal destinations. Annals of Tourism Research, 43, 1-19. doi:10.1016/j.annals.2013.03.005

Kilim Community Cooperative Society (KCCS) (2012). Report on the incoming tourist into Kilim Geopark. Langkawi, Malaysia: Langkawi Development Authority (LADA).

Kock, N. (2015). WarpPLS 5.0 User Manual. Laredo, TX: ScriptWarp Systems.

Kock, N. (2013). WarpPLS 4.0 User Manual. Laredo, TX: ScriptWarp Systems. Retrieved December, 10, 2013. Retrieved from http://www.scriptwarp.com/warppls /UserManual_v_4_0.pdf

Kock, N., \& Lynn, G. S. (2012). Lateral collinearity and misleading results in variance-based SEM: An illustration and recommendations. Journal of the Association for Information Systems, 13 (7), 546-580.

Langkawi Development Authority (2011, October 18). Tourist statistic: Latest tourist statistics. Retrieved from http://www.lada.gov.my/v2/en/information/t ourist-statistic.html

Lawson, F., \& Baud-Bovy, M. (1977). Tourism and recreational development. London, UK: Architectural Pres.

Lee, H., \& Graefe, A. R. (2003). Crowding at an arts festival: extending crowding models to the frontcountry. Tourism Management, 24(1), 1-11. doi:10.1016/S0261-5177(02) 00036-5

Neuts, B., \& Nijkamp, P. (2012). Tourist crowding perception and acceptability in cities: An applied modelling study on Bruges. Annals of Tourism Research, 39 (4), 2133-2153. doi:10.1016/j.annals. 2012.07.016

O'Reilly, A. M. (1986). Tourism carrying capacity: concept and issues. Tourism Management, 7 (4), 254-258. doi:10.1016/0261-5177(86)90035-X

Pike, S., \& Ryan, C. (2004). Destination positioning analysis through a comparison of cognitive, affective, and conative perceptions. Journal of Travel Research, 42 (4), 333-342. doi:10.1177/0047 28750423029

Rasoolimanesh, S. M., Jaafar, M., Kock, N., \& Ahmad, A. G. (2017a). The effects of community factors on residents' perceptions toward World Heritage Site inscription and sustainable tourism development. Journal of Sustainable Tourism, 25(2), 198-216.

Rasoolimanesh, S. M., Jaafar, M., Marzuki, A., \& Abdullah, S. (2017b). Tourist's perceptions of crowding at recreational sites: the case of the Perhentian Islands. Anatolia, 28(1), 41-51.

Rasoolimanesh, S. M., Jaafar, M., Marzuki, A., \& Mohamad, D. (2016). How visitor and environmental characteristics influence perceived crowding. Asia Pacific Journal of Tourism Research, 21(9), 952-967.

Russo, A. P. (2002). The "vicious circle" of tourism development in heritage cities. 
Annals of Tourism Research, 29 (1), 165182. doi:10.1016/S0160-7383(01)00029-9

Rüstemli, A. (1992). Crowding effects of density and interpersonal distance. The Journal of Social Psychology, 132 (1), 5158. doi:10.1080/00224545.1992.9924687

Saveriades, A. (2000). Establishing the social tourism carrying capacity for the tourist resorts of the east coast of the Republic of Cyprus. Tourism Management, 21 (2), 147-156. doi:10.1016/S0261-5177(99) 00044-8

Tapachai, N., \& Waryszak, R. (2000). An examination of the role of beneficial image in tourist destination selection. Journal of Travel Research, 39 (1), 37-44. doi:10.1177/004728750003900105

Um, S., \& Crompton, J. L. (1992). The roles of perceived inhibitors and facilitators in pleasure travel destination decisions. Journal of Travel Research, 30 (3), 18-25. doi:10.1177/004728759203000303

UNWTO (2014). UNWTO tourism highlights, 2014 edition. Madrid, Spain: World Tourism Organization (UNWTO).
Wong, J. Y., \& Yeh, C. (2009). Tourist hesitation in destination decision making. Annals of Tourism Research, 36 (1), 6-23. doi:10.1016/j.annals.2008.09.005

Yagi, C., \& Pearce, P. L. (2007). The influence of appearance and the number of people viewed on tourists' preferences for seeing other tourists. Journal of Sustainable Tourism, 15 (1), 28-43. doi:10.2167/ jost528.0

Yildirim, K., \& Akalin-Baskaya, A. (2007). Perceived crowding in a café/restaurant with different seating densities. Building and Environment, 42 (9), 3410-3417 doi:10.1016/j.buildenv.2006.08.014

Yacob, M. F., Jaafar, M., Marzuki, A., Mohamed, B., \& Bahauddin, A. (2013). Promoting ecotourism product development in Kilim Geopark based on tourists' perceptions. In Proceedings of International Conference on Tourism Development, 'Building the future of tourism', Penang, Malaysia, 4-5 February 2013. (pp. 354-363). Sustainable Tourism Research Cluster. 